\title{
Islamic Education Strategy to Face Challenges of the Era of Industry 4.0
}

\author{
Muslih Muslih \\ Universitas Islam Negeri Walisongo Semarang, Indonesia \\ \{muslih@walisongo.ac.id\}
}

\begin{abstract}
This study aims at revealing the steps Islamic education can take in responding to the challenges of the industrial era 4.0. This era is marked by cyber-physical and manufacturing collaboration with the characteristics of using applied technology. Methodologically, this is a qualitative research. The data obtained came from literature review analysed by philosophical hermeneutics. Responding to challenges and opportunities of the industrial era 4.0, the Indonesian government reviewed the relevance between education and work, while paying attention to human aspects, and proclaimed the new literacy movement focused on three main literacies: digital, technological, and human literacy. Islamic education, as part of the national education system in Indonesia, has responded to the government call in digital, technological, and human literacy by taking serious and systematic preparation in two domains: institutional and learning process, in responding to challenges and opportunities of the industrial era 4.0. The use of digital tools and information technology in today's learning process, such as e-learning confirmed its participation in improving the digital and technological literacy. Its provision of Islamic religious education means also providing good character education, and therefore, confirmed its participation in human literacy.
\end{abstract}

Keywords: Islamic Education; Human Literacy; Era Of Industry 4.0; Character Education

\section{Introduction}

Now we live in the industrial era 4.0, which is marked by the massive use of digital technology in all areas of life: social, economic, legal and educational. In this study I would like to focus on one area, namely education. In this discussion, I want to see how the world of education, specifically Islamic education, responds to the opportunities and challenges existing in the industrial era 4.0, which is the question of this research. The data used in this study came from literature reviews relating to the topic, then analysed by the philosophical hermeneutical method. To obtain a comprehensive understanding of this subject, I present the following points consecutively. First, a brief overview of the 4.0 industrial revolution, then, followed by a discussion on the Indonesian government efforts in facing the industrial era 4.0. In the following section, which is the core of this study, I analysed the strategy or the steps 
taken by Islamic education in responding to the challenges of the industrial era 4.0, and finally, this works is ended with a conclusion.

\section{Literature Review}

\subsection{History of industry 4.0}

The history of the industrial revolution starts from industry 1.0, 2.0, 3.0, to industry 4.0. The industrial phase is a real change from the existing changes. Industry 1.0 is characterized by production mechanization to support the effectiveness and efficiency of human activities, industry 2.0 is characterized by mass production and quality standardization, and industry 3.0 is characterized by mass customization and the flexibility of automation and robot-based manufacturing. Industry 4.0 then comes to replace industry 3.0 that is marked by cyberphysical and manufacturing collaboration $[1, \mathrm{p} .2]$.

The term "Industry 4.0" arose in 2011 from a project in the German government's hightech strategy, which agreed to computerize manufacturing. The term "Industry 4.0" was publicly introduced at the same year at the Hannover Fair. In October 2012, the Working Group on Industry 4.0 presented recommendations for implementing Industry 4.0 to the German federal government. Meanwhile, the phrase Fourth Industrial Revolution was first introduced by Klaus Schwab, executive of the World Economic Forum, in a 2015 article published by Foreign Affairs. According to the German Chancellor, Angela Merkel (2014), Industry 4.0 is a comprehensive transformation of all aspects of production in industry by combining digital technology and the Internet with conventional industries [2]

The digital revolution and the era of technological disruption are other terms for Industry 4.0. It is called the digital revolution because of the proliferation of computers and automation of records in all fields. Industry 4.0 is said to be the era of technological disruption because automation and connectivity in a field will make the movement of the industrial world and job competition non-linear [3, p. 4]. Today, the phenomenon of disruption does not occur only in the business world, but it has also expanded to other fields such as government, culture, politics, law, and education [1, p. 24].

\subsection{Characteristic of Industry 4.0 and Skills Required}

This era has the characteristics of using applied technology such as advanced robotics, artificial intelligence, internet of things, virtual and augmented reality, additive manufacturing, and distributed manufacturing which as a whole is able to change production patterns and business models in various industrial sectors. Having understood of the characteristics of the era of industry 4.0 students must be prepared for it. They must be given better and more comprehensive insights in order to face the challenges of the industrial era of 4.0. Students are agents of social change who will become the successors and leaders of the nation in the future. Therefore, students must be given insights and knowledge that is developing at this time and in the future. They must be seriously prepared to compete in the 21 st century.

There are several skills that everyone must have in order to be able to survive in the industrial era 4.0 of the 21 st century. Concerning this regard, I want to give an assessment that what is conveyed by NESTA is very interesting. NESTA is a British charity that works worldwide as a global innovation foundation. In its digital skills report in 2018, Djumalieva and Sleeman proposed the following 16 skills for the 21 st century. They divided these into 3 
classifications: Foundational Literacies, Competences and Character Qualities. In detail, these 16 skills are as follow: (1) Literacy, (2) Numeracy, (3) Scientific Literacy, (4) ICT Literacy, (5) Financial Literacy, (6) Cultural \& Civic Literacy (Classified as Foundational Literacies). (7) Critical thinking/ Problem-solving, (8) Creativity, (9) Communication, (10) Collaboration (Classified as Competences). (11) Curiosity, (12) Initiative, (13) Persistence/ grift, (14) Adaptability, (15) Leadership, (16) Social and cultural awareness (Classified as Character Qualities) [5, p. 7]. Recognizing the character of the industrial era 4.0 and considering what skills are needed in order to survive and live in that era is important for every student, so that they can anticipate and prepare themselves with this set of skills seriously.

\section{Result and Discussion}

\subsection{Efforts of the Indonesian Government in Anticipating the Industrial Era 4.0}

\subsubsection{Reviewing the Relevance between Education and work}

The challenges and opportunities that exist in the industrial era 4.0 have encouraged innovation in the field of education. Wolter, quoted in Yahya, identifies industry 4.0 challenges as (1) information technology security issues, (2) reliability and stability of production machines, ((3) lack of adequate skills, (4) reluctance to change by stakeholders, and 5) the loss of a lot of work due to turning into automation [1, p. 6]. Meanwhile Irianto, also quoted in Yahya, mentions a number of opportunities in industry 4.0 such as (1) ecosystem innovation, (2) competitive industrial base, (3) investment in technology, and (4) integration of Small and Medium Enterprises and entrepreneurship [1, p. 9]. To anticipate the challenges and opportunities that exist in the industrial era 4.0, the government has taken some necessary actions, for example reviewing the relevance between education and the world of work while still paying attention to human aspects.

\subsubsection{Introducing New Literacy Movement}

Facing this industrial era 4.0, the Indonesian government, through the Ministry of Research and Technology, for example, has countered it with the introduction of new literacy: (1) digital literacy, (2) technological literacy, (3) human literacy [6, p. 24]. These three skills are stated to be skills that are needed in the future or in the industrial era 4.0. Digital literacy is aimed at increasing the ability to read, analyse, and use information in the digital world (Big Data), technological literacy aims to provide an understanding of how machines and technology applications work, and human literacy is directed at increasing communication skills and mastery of design science [1, p. 14]. The new literacy that is given is expected to create competitive graduates by perfecting the old literacy movement which only focuses on improving reading, writing and mathematics skills.

With regard to digital literacy, the term big data appears. Since the widespread use of the Internet such as Facebook, Twitter, Line and Instagram, Internet users are not only consumers but also data producers themselves. Big data can be used to produce knowledge. The definition of big data includes 5V: Volume (large volume), Velocity (rapid growth), Variety (various formats), Value (used value), Veracity (valid). Pertaining to technological literacy, the 4.0 industrial revolution is related to Artificial Intelligence (AI) and autonomous robotics. $\mathrm{AI}$ is an intelligence imitation technique that is owned by humans so that computers have 
intelligence that resembles humans. With AI humans are helped in dealing with various problems or complex environmental phenomena. Autonomous robotic is a robot that can do work without having to be guided by humans. Regarding human literacy, it concerns the ability to communicate well, which is needed by people who manage data (data scientists) that arise because of big data. Big data can be exploited to find new insights that can improve industry performance [6, p. 24].

What is done by the government by introducing this new literacy is a necessity, to face the industrial era 4.0. The government hopes that by increasing their mastery of new literacy students in Indonesia will have reliable competencies and be able to compete with their colleagues from abroad in entering very competitive work competition.

\subsection{Actions of Islamic Education in Responding the Challenges of Industrial Era 4.0}

\subsubsection{Preparing Strategic Steps}

The industrial era 4.0 is also commonly referred to as the disruption era. The era of disruption is a time that threatens and has serious challenges in human life, and people who are unable to adapt to the changes will certainly experience many difficulties in navigating the waves of everyday life that are full of changes and full of competition [7].

Furthermore, looking at the development of the industrial era 4.0, which emphasizes on the big wave of digital transformation, there are only two choices that can be taken by anyone, including academics or education actors in facing this era, namely: first, do nothing to ultimately leads to the hole of destruction due to disruption; second, have strategic steps to anticipate and respond to waves of disruption [8, p. 9].

Of course, as academician or education practitioner we do not want to be swamped by waves of disruption. We have a strong determination to survive in this era, be able to fill opportunities and answer the challenges that exist in the industrial era 4.0. In my opinion, it is significantly urgent for the present time that Islamic education institution prepare strategic steps and implement them as well as possible in the real practice. To anticipate this industrial era 4.0, Islamic education as a subsystem of national education in Indonesia has to take (to some extent, it has been initiated), serious and systematic preparations and anticipatory steps in two domains, namely the institutional and the learning process.

\subsubsection{Institutional Domain}

In the institutional realm, Islamic education providers from elementary (madrasah ibtidaiyah or Islamic elementary school) to tertiary institutions (universities, such as UIN, IAIN, STAIN) has commenced to make changes and adaptations in several ways. Firstly, prepare and develop the quality of human resources who master science and technology, who are creative, innovative, adaptive, and have a good personality. Secondly, Islamic educational institutions also need to adapt their curricula to the changes and demands of the times and the rapid development of technology. Some institutions, of course, have already taken this action seriously. Currently the development and implementation of the curriculum has been integrating information technology, therefore in the learning process and teachers have to master the information technology. In fact, students and teachers have been actively involved in the learning process by utilizing technology, either as a source, media or as a learning tool. Now, the learning paradigm has shifted towards digital-based learning. Learning models have developed in the form of electronic learning (e-learning), electronic books (e-books), online 
classes, online discussions, and computer-based learning [9, p. 32]. Thirdly, Islamic educational institutions must also provide educational facilities and infrastructure that support the massive application of digital technology today.

No need to argue that doing all of this is not easy task and cannot be imposed only on the government alone. However, it takes synergic cooperation between the government and the community. The government, in this case the Ministry of Religious Affairs of the Republic of Indonesia, as the umbrella of Islamic education institutions, must provide funds and create relevant quality programs to improve the performance of Islamic education providers to a better level. For example, the program intended to increase the basic competences of the teaching staff, both teachers and lecturers, who will become the driving force in each educational activity of their respective institutions.

\subsubsection{Learning Process Domain}

In the realm of the learning process, all students at all levels of Islamic education institutions from elementary to tertiary institutions must be introduced and familiarized with the use of technology in their interactions and learning activities For institutions that have already begun this step, they can increase it even more intensely. Therefore, mastery of technology (technological literacy) is an absolute thing that must be owned by educators and students. Currently, e-learning, especially with the COVID-19 pandemic, is an inevitable choice for education actors in Indonesia to implement, including Islamic education. Currently, e-learning is starting to attract the attention of many parties: academics, professionals, companies and industries [8, p. 12]. Hoyles \& Lagrange, quoted in Putrawangsa, emphasized that digital technology is the thing that most influences the education system in the world today. This is due to the aspects of effectiveness, efficiency and attractiveness offered by digital technology-based learning [10, p. 43]. In fact, this e-learning model has been implemented in all Islamic education institutions (under the auspices of Ministry of Religious Affairs), due to the government's recommendation not to physically open classes during the Covid-19 pandemic.

The old model of education that relies on physical face-to-face meetings in the classroom, as happened so far, seems to be no longer suitable in the current conditions and cannot be maintained anymore, as it is not effective. In fact, mastery of technology has begun to be practiced in the teaching and learning process in Islamic educational institutions today [9]. This can be interpreted as a form of participation of Islamic education in responding to the technological literacy movement proposed by the government (the Ministry of Research and Technology).

Likewise, in its learning process, Islamic education as a subsystem or part of Indonesian national education system has made a real contribution in responding to the challenges and opportunities of the era of industry 4.0, especially with good character education it presents to strengthen the human literacy. Giving good character education in the learning process is urgent and at stake for Indonesian students at the moment, to reduce the spread of fake news and hoaxes, resulted from the lack of critical thinking, which is one of the demands in the era of industry 4.0 .

Islamic education institutions from elementary to tertiary level are the best places where students get Islamic religious education that can shape their good morals and character. In the teaching and learning process they experience, the organizers of Islamic education (from madrasah ibtidaiyah to UIN, IAIN and STAIN) need to strengthen their position and establish 
their identity as a base that can shape the character of students according to the values, norms and culture of the Indonesian nation.

The employment of Islamic education that has occurred so far needs to be maintained and improved in terms of quality. Revitalization of character education can be done through the provision of good Islamic religious education. Character education provided by Islamic education institutions through Islamic religious education can be understood as a form of Islamic education participation in the government's call for human literacy in anticipating the challenges of the industrial era 4.0.

\section{Conclusion}

As a subsystem or part of the Indonesian national education system, Islamic education must adapt more to the developments that occur nationally and globally. The presence of digital technology in the era of industry 4.0, known also as disruption era, makes education in Indonesia, including Islamic education, have no choice other than to improve, adapt to the changes, and rearrange the strategies so that they can survive the onslaught of this disruptive era. Good character education, which has been the hallmark of Islamic education institutions, needs to be implemented more vigorously and revitalised. Furthermore, Islamic education in its institutional managerial manner as well as in its content and learning process must participate more in implementing digital technology to prepare students to be able to compete with others and be able to fill the opportunities and respond the challenges that exist in the industrial era 4.0. Like institution of national education (under the authority of Ministry of Research and Technology or Ministry of National Education), Islamic education institution, which is administratively under the jurisdiction of the Ministry of Religious Affairs, must appear in front and participate more in responding to government calls in terms of digital literacy, technological literacy and human literacy to respond the challenges of this $21 \mathrm{st}$ century. All Islamic education institutions have a moral obligation to fulfill this government's hopes.

\section{References}

[1] M. Yahya, "Era Industri 4.0: Tantangan dan peluang Perkembangan Pendidikan Kejuruan Indonesia. Pidato pengukuhan penerimaan jabatan professor tetap dalam bidang ilmu pendidikan kejuruan fakultas teknik Universitas Negeri Makassar," Makassar, 2018.

[2] H. Prasetyo and W. Sutopo, "Perkembangan Keilmuan Teknik Industri Menuju Era," pp. 8-9, 2017.

[3] H. Hamdan, "Industri 4.0: Pengaruh Revolusi Industri Pada Kewirausahaan Demi Kemandirian Ekonomi,” J. Nusant. Apl. Manaj. Bisnis, vol. 3, no. 2, p. 1, 2018, doi: 10.29407/nusamba.v3i2.12142.

[4] B. Prasetyo and U. Trisyanti, "Revolusi industri 4.0 dan tantangan perubahan sosial. Prosiding SEMATEKSOS 3 'Strategi Pembangunan Nasional Menghadapi Revolusi Industri 4.0,"” pp. 22-27.

[5] OECD, "Future of Education and Skills 2030: Conceptual Learning Framework," 2018.

[6] A. P. Natasuwarna, "Tantangan Menghadapi Era Revolusi 4.0 -Big Data dan Data Mining," vol. 29 Juli 20, pp. 23-27, 2019. 
[7] R. Kasali, Disruption: Tak Ada yang Tak Bisa Diubah Sebelum Dihadapi, Motivasi Saja Tidak Cukup. Jakarta: Gramedia Pustaka Utama, 2017.

[8] K. Harto, "Tantangan dosen ptki di era industri 4.0," vol. 16, no. 1, pp. 1-15, 2018.

[9] T. Priatna, "Inovasi Pembelajaran PAI Di Sekolah Pada Era Disruptive Innovation," J. Tatsqif, vol. 16, no. 1, pp. 16-41, 2018, doi: 10.20414/jtq.v16i1.158.

[10] S. Putrawangsa and U. Hasanah, "Integrasi Teknologi Digital dalam Pembelajaran di Era Industri 4.0,” vol. 16, no. 1, pp. 42-54, 2018. 